\title{
Review \\ Mechanisms of Genome Instability in the Fragile X-Related Disorders
}

\author{
Bruce E. Hayward and Karen Usdin *
}

check for updates

Citation: Hayward, B.E.; Usdin, K. Mechanisms of Genome Instability in the Fragile X-Related Disorders. Genes 2021, 12, 1633. https:/ / doi.org/ 10.3390 /genes12101633

Academic Editors: David E. Godler and William Ted Brown

Received: 20 September 2021

Accepted: 14 October 2021

Published: 17 October 2021

Publisher's Note: MDPI stays neutral with regard to jurisdictional claims in published maps and institutional affiliations.

Copyright: (c) 2021 by the authors. Licensee MDPI, Basel, Switzerland. This article is an open access article distributed under the terms and conditions of the Creative Commons Attribution (CC BY) license (https:/ / creativecommons.org/licenses/by/ $4.0 /)$.
Section on Gene Structure and Disease, Laboratory of Cell and Molecular Biology, National Institute of Diabetes, Digestive and Kidney Diseases, National Institutes of Health, Bethesda, MD 20892, USA; bruce.hayward@nih.gov * Correspondence: karenu@nih.gov

\begin{abstract}
The Fragile X-related disorders (FXDs), which include the intellectual disability fragile $X$ syndrome (FXS), are disorders caused by expansion of a CGG-repeat tract in the $5^{\prime}$ UTR of the X-linked FMR1 gene. These disorders are named for FRAXA, the folate-sensitive fragile site that localizes with the CGG-repeat in individuals with FXS. Two pathological FMR1 allele size classes are distinguished. Premutation (PM) alleles have 54-200 repeats and confer the risk of fragile Xassociated tremor/ataxia syndrome (FXTAS) and fragile X-associated primary ovarian insufficiency (FXPOI). PM alleles are prone to both somatic and germline expansion, with female PM carriers being at risk of having a child with $>200+$ repeats. Inheritance of such full mutation (FM) alleles causes FXS. Contractions of PM and FM alleles can also occur. As a result, many carriers are mosaic for different sized alleles, with the clinical presentation depending on the proportions of these alleles in affected tissues. Furthermore, it has become apparent that the chromosomal fragility of FXS individuals reflects an underlying problem that can lead to chromosomal numerical and structural abnormalities. Thus, large numbers of CGG-repeats in the FMR1 gene predisposes individuals to multiple forms of genome instability. This review will discuss our current understanding of these processes.
\end{abstract}

Keywords: repeat mosaicism; chromosome fragility; repeat expansion; repeat contractions; aneuploidy; break induced replication (BIR); base excision repair (BER); microhomology mediated end-joining (MMEJ); mitotic DNA synthesis (MiDAS)

\section{Introduction}

In the late 1940s, J. Purdon Martin and Julia Bell described an extended family with 13 cases of intellectual disability and an unusual pattern of X-linked inheritance in which the traits could be transmitted by males who displayed no clinical symptoms [1] to males in later generations who did. It was more than 20 years later that a "marker X chromosome", showing the chromosome abnormality we now call a fragile site, was first shown to cosegregate with these traits [2]. Originally known as Martin-Bell syndrome, the fragile site eventually gave this disorder the name we know it by today, fragile X syndrome (FXS: OMIM \# 300624). The fragile site, FRAXA, a chromosome constriction, gap, or break is seen at the end of the long arm of the X chromosome in metaphase cells subjected to folate-stress. The site became an important diagnostic marker for FXS that was used until the early 1990s, when the gene responsible for this disorder was identified and Southern blotting became the gold standard for diagnosis. The most common mutation associated with FXS is a large and unstable CGG-repeat tract in the 5' UTR of the FMR1 gene (MIM* 309550) [3,4]. FMR1 encodes FMRP, an RNA-binding protein important for learning and memory. The repeat tract, which is coincident with the fragile site at Xq27.3, explains the unusual inheritance pattern that had become known as the Sherman paradox; the repeat is expansion prone, tending to gain repeats with each successive generation, with symptoms of FXS only becoming apparent when the repeat number exceeds 200 [5]. Such alleles are known as full mutation (FM) alleles and the symptoms of this disorder arise because the FM allele undergoes a process of repeat-mediated gene silencing that results in a deficit of FMRP [6]. 
FM alleles originate from maternally transmitted alleles with 54-200 repeats. These alleles, known as premutation (PM) alleles, are not associated with intellectual disability, but do confer the risk of a form of ovarian dysfunction known as fragile $\mathrm{X}$-associated primary ovarian insufficiency (FXPOI: OMIM \# 311360) [6]. Both male and female PM carriers are also at risk of an adult-onset form of neurodegeneration known as fragile $\mathrm{X}$-associated tremor/ataxia syndrome (FXTAS: OMIM \# 300623) [6]. PM pathology is thought to result from the deleterious consequences of having long CGG-repeat tracts in the FMR1 transcript (reviewed in [7]). The disorders seen in carriers of PM and FM alleles are known collectively as the FMR1 disorders, the fragile $\mathrm{X}$ spectrum disorders, or the fragile $\mathrm{X}$ related disorders (FXDs) for the fragile site that once served as a diagnostic feature of FXS [6].

In addition to the expansions that cause these disorders, contractions of the repeat and deletions associated with the loss of flanking sequences are also associated with PM and FM alleles. In some cases, this generates a normal sized allele [8-11]. In other cases, a deletion involving the repeat and a variable amount of one or both flanking sequences is seen. The consequences of these deletions depend on how far they extend into the $5^{\prime}$ and $3^{\prime}$ flanking regions. Some cases involve a minimal loss of flanking sequence, with a normal phenotype resulting if the repeat number is now in the normal range [12-15]. Other cases involve a deletion of the entire FMR1 gene or critical regions of exon 1. This can result in a deficit of FMRP, resulting in a phenocopy of the symptoms seen in FM carriers $[8,16]$. Contraction events that generate a single allele that is present in all cells presumably occur prezygotically $[9,10,15]$, but contractions can occur post-zygotically, resulting in individuals who are mosaic for different sized alleles [10,11,17-20]. It has been estimated that $38 \%$ of FM carriers are mosaic for additional FM alleles, PM alleles, or both [21]. This mosaicism results in a variable phenotype depending on the proportion of cells that have normal, PM, or FM alleles and, for those individuals with PM alleles, the size distribution of those alleles [22-24]. In addition to repeat instability, an increased incidence of the loss of the end of the long arm of the affected X chromosome has been shown in early FXS embryos [25]. A high risk of mosaic Turner syndrome, caused by the loss of the affected X chromosome, has also been reported in female FXS fetuses [26]. Thus, expanded CGG-repeat tracts cause two forms of genetic instability, one involving localized changes in and around the repeat tract, while the second causes chromosome instability, resulting in loss of all or part of the affected chromosome, which is seen in some carriers of FM alleles.

There are several other diseases resulting from unstable CGG-repeat tracts and their associated folate-sensitive fragile sites [27]. The mechanisms of instability and fragility at these loci are likely to be similar to those operating at the FMR1 locus. These diseases belong to a much larger group of clinical conditions known as the repeat expansion diseases that all result from expansion of a disease-specific short tandem repeat tract [28]. Whether these diseases all share a common expansion mechanism is the subject of much debate, but, as will be discussed later, evidence from common genetic modifiers of expansion risk in some of these diseases and in the mouse models of these diseases suggests that they may do so. Repeat instability and chromosome fragility have been reported in many different organisms and several mechanisms have been proposed to explain these phenomena (see [29-31] for excellent recent reviews). It has been suggested that there may be a common underlying mechanism responsible for both expansions and deletions/contractions in the repeat expansion diseases, one that is also shared with chromosome fragility. However, what best explains events occurring at the FMR1 locus in PM and FM carriers is still an open question. This review will discuss evidence from PM and FM carriers and patients with other repeat expansion diseases that allows us to narrow our focus to a subset of possible mechanisms that account for these events.

\section{FRAXA Chromosome Fragility}

By metaphase, chromosomes are normally fully condensed in preparation for anaphase and cytokinesis. However, at this stage, fragile sites have a microscopic appearance consistent with chromatin that has not yet been condensed. In the case of FRAXA, expression 
of the fragile site is limited to FM alleles that are transcriptionally silenced [32]. This does not mean that silencing per se is required for fragility. Rather, it may reflect the fact that silenced alleles replicate later in the cell cycle than transcriptionally active ones. Normal alleles replicate late in S phase, while FM alleles replicate in G2/M under normal growth conditions [33]. When replication is further delayed because of folate stress, more cells enter mitosis without having completed replication of the FMR1 region [33,34].

In contrast to the many fragile sites induced by aphidicolin, a DNA polymerase inhibitor, FRAXA and other fragile sites associated with long CGG-repeat tracts are induced by treatments that negatively impact thymidylate synthase, and thus the size and composition of the nucleotide pools available for replication [35]. CGG-repeats form stable intrastrand structures, including hairpins and quadruplexes, that contain a mixture of base mismatches or non-canonical base interactions [36-44]. These structures block DNA synthesis in vitro and are thought to be responsible for the blocks to DNA replication seen in cell models [45] as well as the delayed replication of FM alleles [32,46]. FX cells treated with 5-fluoro-2'-deoxyuridine (FdU), a direct inhibitor of thymidylate synthase, show an increase not only in the expression of the fragile site, but also in the incidence of ultrafine anaphase bridges arising at the FMR1 locus [47]. These ultrafine bridges stain with DAPI, a DNA stain, but do not contain histones. They are also associated with RPA, a single-stranded DNA binding protein, suggesting the presence of single-stranded DNA. Accumulation of these RPA+ve ultrafine bridges depends on RAD51, a protein essential for homologous recombination. This suggests that the ultrafine bridges represent unresolved homologous recombination intermediates. These ultrafine bridges are seen even in the absence of FdU, indicative of problems at this locus even under normal growth conditions. Examination of binucleated G1 cells shows a high frequency of daughter cells that either lack the FM allele or have a FRAXA-positive micronucleus [47]. Extended growth in FdU results in the high frequency loss of the entire $X$ chromosome carrying the FM allele, linking replication problems, fragility, and aneuploidy [47].

FM alleles undergo mitotic DNA synthesis (MiDAS) in response to folate stress [48]. MiDAS is thought to be a salvage pathway used by cells to ensure that genomic regions are duplicated before cell division occurs. As illustrated in Figure 1, MiDAS at FM alleles occurs via a RAD52-independent, but RAD51-dependent process that requires POLD3,

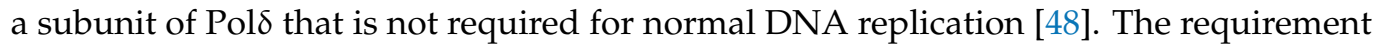
for POLD3 suggests that MiDAS involves a break-induced replication (BIR)-like process. BIR is generally initiated by a one-ended break generated by cleavage of a stalled replication fork, or similar structure, by a structure selective endonuclease. In the case of FM alleles, the endonuclease involved is SLX1/SLX4 [48]. Following cleavage and $5^{\prime}$ to $3^{\prime}$ end resection, RAD51 is thought to bind to the free $3^{\prime}$ single stranded region and facilitate strand invasion, as illustrated in Figure 1 [48]. This is followed by a form of conservative replication that allows this region of the chromosome to be properly duplicated. Inhibition of MiDAS prevents chromosome fragility but increases the frequency of chromosome mis-segregation [48]. It has been suggested that fragility is the result of the delayed chromosome condensation that occurs when MiDAS has been initiated but does not get completed in time [48]. This leaves the chromosome prone to breakage, and that might account for the high frequency of terminal deletions that have been observed in FXS embryos [25]. BIR also involves frequent template-switching. Copy number variations can frequently result because of this process when mispriming occurs within repeats. Chromosome missegregation, on the other hand, has been suggested to result from the failure to initiate MiDAS at all [48]. This mis-segregation could account for the high frequency loss of the affected X chromosome in female fetuses carrying a FM [26]. Similar events are likely to be associated with other folate-sensitive fragile sites. 


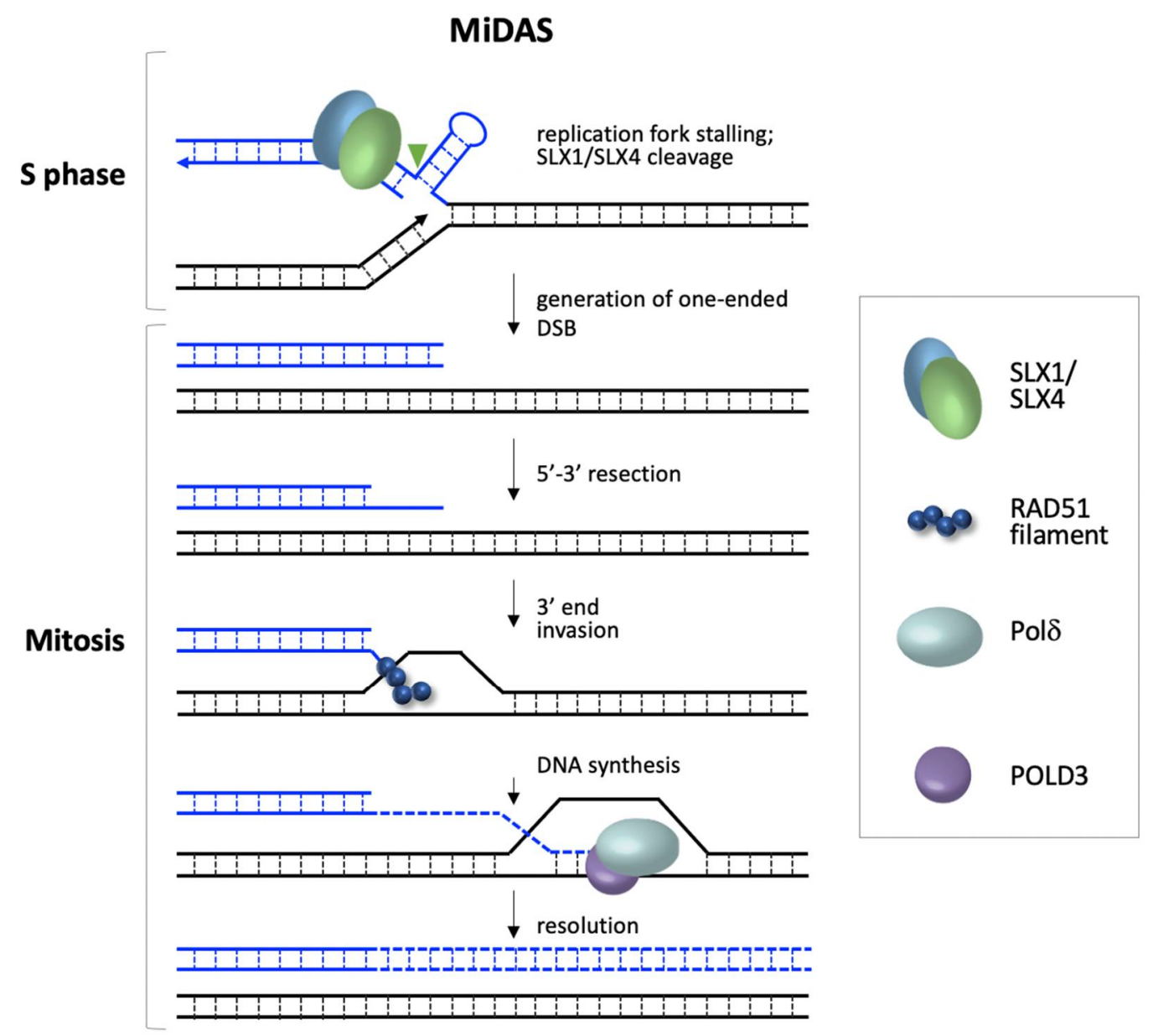

Figure 1. Model for mitotic DNA synthesis (MiDAS) at the FMR1 locus. FM alleles with stalled replication forks that have not been resolved by the time mitosis begins are cleaved by the SLX1/SLX4 nuclease to generate a one-ended DSB. After end resection to generate a $3^{\prime}$ overhang, binding of RAD51 allows the exposed $3^{\prime}$ end to invade a homologous template, likely a sister chromatid. Conservative DNA synthesis then occurs in a POLD3-dependent fashion to complete replication [48]. Failure to initiate this process results in the formation of ultrafine bridges and the high frequency loss of the affected $X$ chromosome [26,48], while failure to complete MiDAS results in fragile site expression [48].

\section{Repeat Instability}

The risk of CGG-repeat expansion at the FMR1 locus is known to be directly related to the length of the repeat tract and inversely related to the number of AGG interruptions often present at the $5^{\prime}$ end of the repeat tract $[21,49,50]$. In female PM carriers, expansions outnumber contractions by a factor of 10 to 1 [50] and, when the repeat number approaches 90 , there is close to $100 \%$ probability of an intergenerational transmission of an allele that now has $>200$ repeats [50,51]. Increasing maternal age also increases the expansion risk [51]. While FM alleles are only maternally transmitted, at smaller repeat lengths, paternal alleles are prone to expand in gametes [52] and small expansions are more frequent on paternal transmission than on maternal transmission [50].

Once alleles expand into the FM range and become methylated, the repeat tract ceases to be expansion-prone [53,54]. It is also evident that expansion in female PM carriers only occurs when the PM allele is on the active chromosome [55]. These observations suggest that transcription or a euchromatic chromatin configuration is required for repeat expansion. The expansion profiles seen in the blood of females with PM alleles [56] are consistent with mathematical modelling suggesting that expansion proceeds via the frequent gain of a small number of repeats, on average $\sim 1-2$ repeats/event [57]. In contrast, large contractions accumulate rapidly in somatic cells in culture [58]. 
While the hypothesis that contractions and expansions result from the same underlying process is reasonable, there is evidence to suggest that this is not the case. For example, slowing replication with FdU in lymphoblasts from human PM carriers results in contractions, but not expansions [47]. While it is possible that this reflects selection for smaller alleles when cells are subject to replication stress, contractions of silenced FM alleles are readily seen in tissue culture, suggesting that, in contrast to expansions, some contractions do not require transcription [58]. In addition, while most somatic expansions occur via the addition of a small number of repeats with each event, contractions generally result in large and variable changes in repeat number. Furthermore, while AGG interruptions significantly reduce the intergenerational expansion frequency, they have no effect on the frequency of both maternally and paternally transmitted contractions in FX families [50]. Given that fragility is seen only on non-transcribed alleles and expansion is only seen on transcriptionally active alleles, a common trigger for expansion and fragility is also unlikely.

\subsection{Repeat Expansions}

To date, no genome-wide association studies of PM carriers has been done to identify trans-acting genetic factors involved in the CGG-repeat expansion process at the FMR1 locus. However, expansions in the FXDs share many similarities with other repeat expansion diseases. This includes the small number of repeats gained with each expansion event, their frequency, their dependence on transcription, and the fact that expansion occurs in non-dividing cells. In fact, expansions in non-dividing striatal neurons in Huntington disease can result in the gain of many hundreds of repeats during an individual's lifetime [59]. Work from some of these diseases, including Huntington disease (HD), myotonic dystrophy type 1 (DM1), and many spinocerebellar ataxias, has implicated some of the proteins involved in mismatch repair (MMR) in the expansion in somatic cells $[60,61]$. Specifically, MSH3, MLH1, and MLH3, are thought to be involved in promoting expansions, while FAN1, which has recently been shown to also play a role in MMR, has a protective effect [62].

These same proteins play equivalent roles in promoting and protecting against both somatic and germline expansions in a knock-in mouse model of the FXDs [63-66]. There are a number of other parallels between expansion in this mouse model and instability in PM carriers and individuals with other repeat expansion diseases, including the high frequency of small expansions [55], a requirement for transcription [67], and the fact that expansion occurs in non-dividing cells [68]. It is formally possible that different expansion mechanisms operate in dividing and non-dividing cells. However, in the FXD mouse model, the same genetic factors that are required for expansion in dividing cells are required for expansion in non-dividing ones. Thus, at least in this model, a similar mechanism of expansion likely operates in all expansion-prone cell types.

$\mathrm{MSH} 2$, the binding partner of MSH3 in the MutS $\beta$ complex, is also required for expansion in the FXD mouse model [69], while MSH6, the MSH2 binding partner in the MutS $\alpha$ complex, plays an important auxiliary role [65]. It has been shown that the nuclease activity of MLH3 is required for expansion [70]. This is interesting because MLH3 is a relatively minor player in MMR, although it plays a critical role in meiosis [71], where it is involved in processing Holliday junctions into crossover products [72]. In addition to MLH3, expansion in the FXD mouse model also requires PMS1 and PMS2 [73]. All three proteins are binding partners of MLH1, forming MutL $\alpha$ (MLH1/PMS2), MutL $\beta$ (MLH1/PMS1), and MutL $\gamma$ (MLH1/MLH3). The requirement for all three MutL complexes is perplexing because they have not been shown to act in concert in MMR. Furthermore, the role of MutL $\beta$ is intriguing because, while it is much more abundant than MutL $\gamma$, it lacks nuclease activity and has no clearly defined role in MMR. The protective role of both FAN1 and EXO1, another nuclease involved in MMR that also protects against expansion in the mouse model [64], might be explained by competition for the products of MutL cleavage between the canonical MMR pathway, which restores the original allele, and an alternative pathway that leads to expansion. 
Why transcription is required for repeat expansion is unknown. One early idea in the field was that it could be related to problems associated with long CGG-repeat tracts that were resolved by transcription coupled repair (TCR), the major DNA repair pathway limited to transcribed regions of the genome [74]. However, CSB, a protein essential for TCR, is not required for expansion in the mouse model [75,76]. More recently, it has been shown that stable R-loops form at the FMR1 locus [77-80] and, potentially, these R-loops could be processed into double strand breaks. Because, in the FXD mouse model, nonhomologous end-joining, the major double-strand break (DSB) repair pathway operating in mammalian cells, protects against expansion [56], expansion in these animals likely involves a DSB intermediate. However, direct R-loop processing into double-strand breaks is also dependent on CSB [81,82]. R-loops could act as the trigger for expansion in other ways. For example, the single-stranded regions of DNA present in R-loops are likely to be prone to oxidative damage, frequently generating 8-oxo-7,8-dihydroguanine (8-oxoG), the most common product of oxidative damage. As illustrated in Figure 2, such damage may be processed via the base excision repair (BER) pathway, the major pathway for the repair of such damage in mammalian cells. Strand slippage/displacement during long-patch BER may facilitate the formation of hairpins that we have shown to be effectively bound by MutS $\beta$ and MutS $\alpha$ in vitro [65]. A role for BER in expansion is suggested by the fact that mutations in OGG1 and NEIL1, DNA glycosylases important for repair of 8-oxoG, reduce expansions in a mouse model of HD [83,84].

\section{Mismatch repair-dependent expansion}

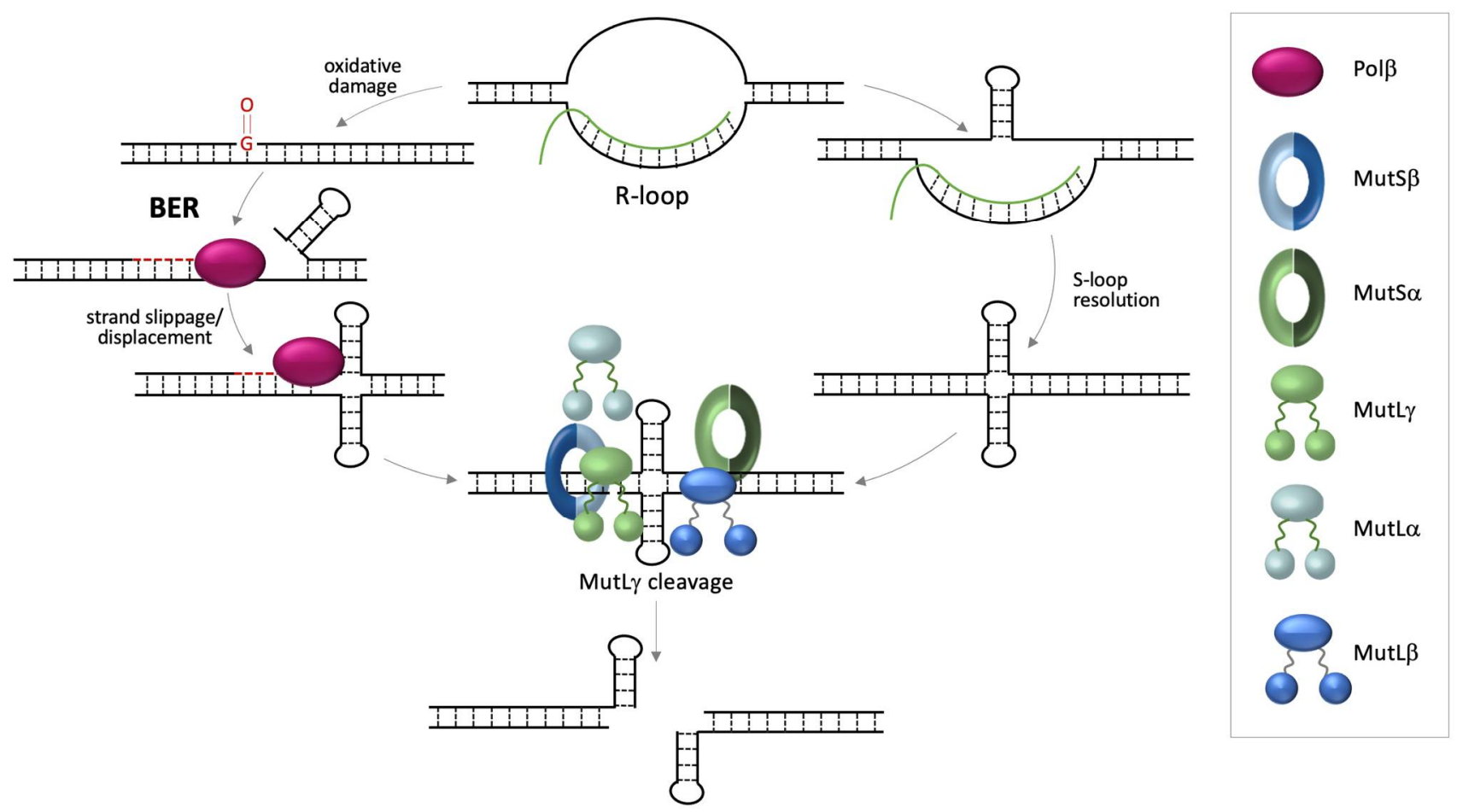

Figure 2. Diagrammatic representation of possible transcription-related, MMR-dependent events that could give rise to repeat expansions. As illustrated on the left-hand side of this figure, R-loops could give rise to expansions because single stranded regions of the R-loop would be prone to oxidative damage. Repair of this damage by BER would create an opportunity for strand slippage and strand-displacement that could result in the formation of hairpins or loop-outs on one or both strands [83]. Alternatively, as illustrated on the right, hairpin formation might occur on the non-template strand of the R-loop, forming an S-loop. This might favor formation of a hairpin on the template strand after dissociation of the transcript. Hairpins or double loop-outs formed by either process could then be bound by both MutS proteins. This results in the recruitment of MutL $\alpha, \operatorname{MutL} \beta$, and MutL $\gamma$. MutL $\gamma$ cleavage of the strands opposite each loop-out would generate a DSB that would then be repaired by some, as yet unknown, non-homologous end-joining-independent DSBR pathway. 
As illustrated on the right-hand side of Figure 2, the non-template strand of the R-loop formed at the FMR1 locus likely forms an intra-strand structure in patient cells $[78,80]$. Resolution of the R-loop would leave the template strand without a complementary strand with which to hybridize and this could result in the formation of a double loop-out structure that would also be predicted to bind MutS $\beta$ and MutS $\alpha$ [65]. Cleavage by MutL $\gamma$ occurs on the strand opposite the mismatched lesion [85]. Thus, MutL $\gamma$ processing of double loop-outs formed either during BER or simply by transcription itself could result in the generation of a DSB that is repaired in some way to generate expansions.

A CGG-reporter construct integrated into a murine erythroid leukemia cell line shows both expansions and contractions occurring at approximately equal frequencies. These events depend upon the Pol $\delta$ subunit POLD3 and the recombination proteins RAD51 and RAD52 [86]. It is probable that these changes arise via some form of BIR that is likely similar to the process shown in Figure 1, except for the fact that RAD52, as well as RAD51, is required. A $3^{\prime}$ single stranded region resulting from a break within the repeat would contain repeats that could potentially anneal out of register on the invaded chromosome or chromatid. This would ultimately generate expansions or contractions depending on whether annealing and subsequent priming occurred upstream or downstream of the breakpoint. Multiple template-switching events, which are known to occur at the early stages of BIR, could also potentially result in the gain or loss of repeats. While BIR is usually involved in the repair of one-ended breaks originating at a stalled replication fork, it has been suggested that BIR can be initiated at double-strand breaks induced in R-loops [87]. Thus, a BIR-dependent process triggered by an R-loop may allow expansion in both dividing and non-dividing cells [88]. However, R-loop mediated BIR has been reported to be CSB-dependent [89]. Furthermore, the BIR associated with FRAXA chromosome fragility is dependent on the SLX1/SLX4 endonuclease to generate the one-ended break [48]. The use of this nuclease to initiate BIR would seem to obviate the need for the MutL $\gamma$ nuclease. MutL $\gamma$ does generate double-strand breaks by cleavage of R-loops in yeast [90], so it could be that MutL $\gamma$ cleavage of R-loops provides the trigger for BIR-mediated repeat expansion. However, this cleavage is independent of the MutS proteins, at least in yeast. BIR-mediated CAG-expansions in yeast are also independent of MSH2, MSH3, and MSH6 [91].

While the loss of MMR proteins such as MLH3 eliminates most, if not all, expansions in mice, it could be argued that, in humans, some expansions arise via an MMR-independent mechanism. In particular, it has been suggested that the large increases in repeat number associated with FM alleles inherited from female PM carriers might arise from a mechanism that generated a large expansion in a single event. BIR has been proposed as just such a mechanism [86]. However, the BIR-dependent expansions in the mouse erythroid leukemia cell reporter system occur at a frequency many orders of magnitude lower than the repeat expansions seen in the FXD mouse model and generally involved the gain of fewer than 30 repeats [86]. Whether the frequency of such events would be high enough in the human oocyte to explain the large gains in repeat numbers seen on maternal transmission of PM alleles is unclear, particularly because contractions, which occurred at a similar frequency and tended to be larger in magnitude than the expansions, would potentially be able to offset some of these gains.

\subsection{Repeat Contractions}

When cells from PM carriers are grown in the presence of FdU, contractions rather than expansions are observed [47]. This might reflect the difficulty of replication through the repeat tract, a phenomenon that would be exacerbated by the reduced availability of nucleotides in FdU-treated cells. As mature sperm in adult men have undergone many more rounds of cell division than oocytes in women of the same age [92], selection for contractions in replicating cells may explain why PM males do not transmit FM alleles and why males with FM alleles in somatic cells have PM alleles in their sperm [93].

Silenced FM alleles do contract [20,58], thus some contractions must be transcription independent. Furthermore, the loss of MMR proteins that are required for expansion results 
in an increase in contractions in the FXD mouse model. These findings reinforce the idea that expansions and at least some contractions arise via different mechanisms. Of interest is the fact that one class of contractions that increases in MMR-deficient cells is associated with the loss of 1-2 repeats. This loss occurs in a large fraction of alleles in mESCs with null mutations in MutL $\alpha$ or MutL $\gamma$ [73]. These small contractions are likely the products of strand-slippage occurring during replication that are normally repaired by MMR, as illustrated in Figure 3A. This might suggest that most strand-slippage events are small and that larger contractions occur via a different mechanism.

A

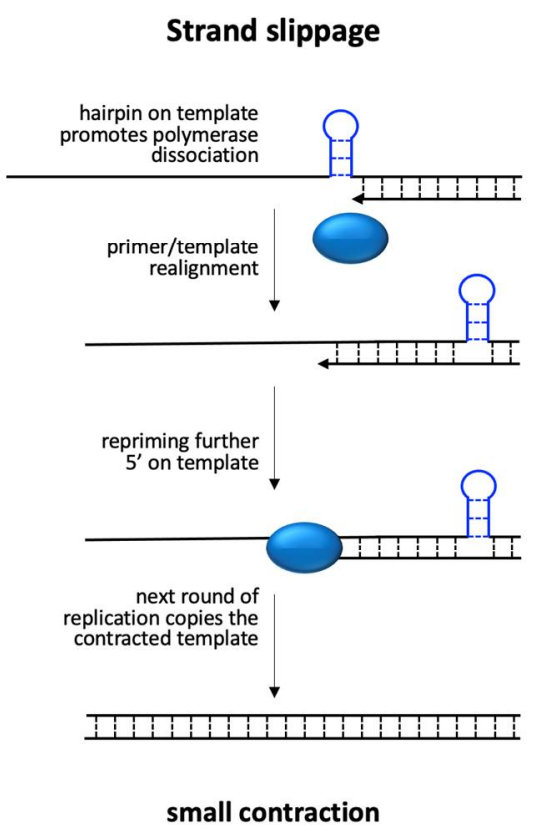

B

Microhomology-mediated end joining

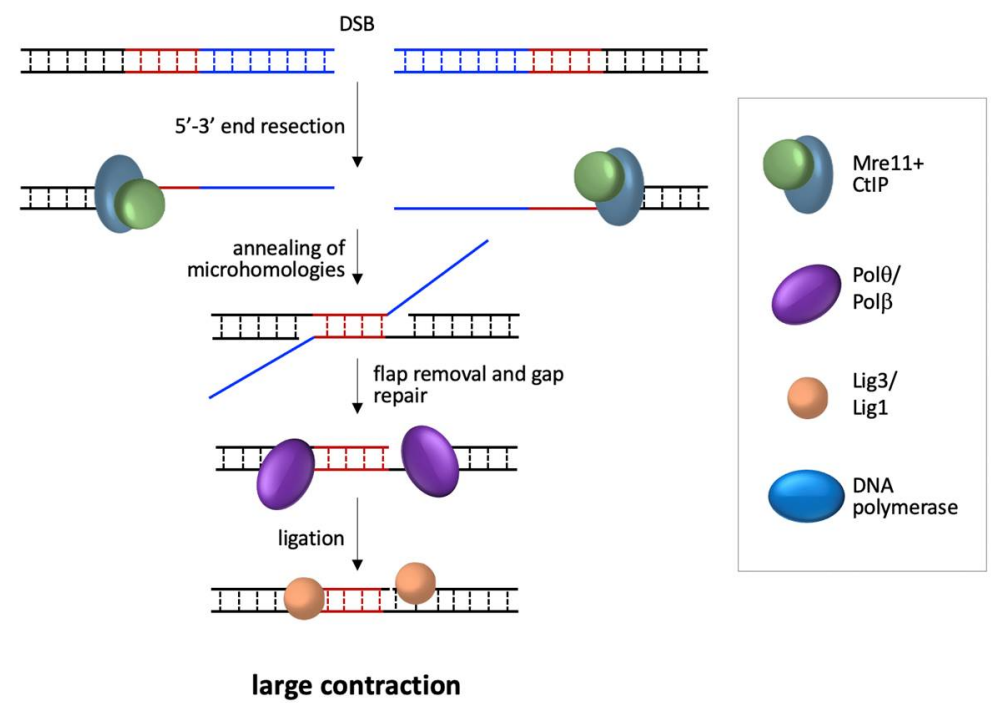

Figure 3. Diagrammatic representation of potential contraction/deletion pathways. (A) Strand-slippage during replication may be exacerbated by hairpins formed on the template strand. Repriming more $5^{\prime}$ on the template would lead to nascent strands with fewer repeats than the template strand. A subsequent round of replication would generate a contracted allele. (B) MMEJ-mediated repair of a DSB is initiated by end-resection to reveal MHs at either side of the break. Annealing of these MHs is followed by removal of non-homologous flaps, filling of any gaps, perhaps by Pol $\theta$ or Pol $\beta$, and ligation by either ligase 3 (Lig3) or ligase 1 (Lig1).

Notably, most of the breakpoints of larger deletions seen in the children of PM and FM carriers that have been characterized at the sequence level are associated with microhomologies (MHs) of 2-9 nucleotides [8,12-16,23,94-101]. Despite the GC-richness of the FMR1 locus that reduces the sequence space, it is possible that such MHs reflect the mechanism involved in the generation of these deletions. Such MHs are the hallmarks of a process known as microhomology mediated end joining (MMEJ). As illustrated in Figure 3B, the process of MMEJ involves end-resection of the DSB by Mre11 and CtIP, followed by a search for short MHs in the two DNA single-stranded tails, annealing of the regions of microhomology, removal of the non-homologous flaps, gap filling, and finally ligation.

Breaks with minimal resection could result in deletions within the repeat (contractions), while more extensive resection would result in deletions that extend into the flanking regions. MMEJ is often accompanied by nucleotide insertions at break sites. The insertions are often derived from sequences close to the breaks or are added de novo because of non-templated extension of the $3^{\prime}$-termini of breaks. These insertions are characteristic of

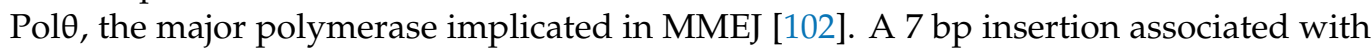
a deletion that extended both upstream and downstream of the repeat has been reported in the son of a mother with a FM allele [8]. In addition, three examples of the de novo generation of an EagI site associated with a contraction of the repeat have been reported 
in humans [103-105]. As the EagI recognition site is CGGCCG, the new site could arise either from a base substitution or from the insertion of a CCG triplet. We have observed the de novo generation of a SmaI site (CCCGGG) within the repeat in our FXD mouse model that might have arisen the same way (Zhao and Usdin, unpublished observations). Thus,

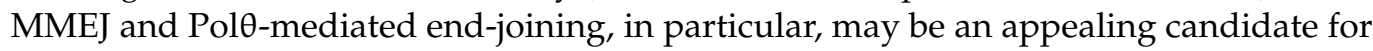
the process that generates contractions or deletions in PM and FM carriers.

\section{Concluding Remarks}

In summary, expanded repeats at the FMR1 locus represent a triple threat to the genome. As illustrated in Figure 4, one threat is present in the form of repeat expansion that leads to the FXDs, the second in the form of deletions that can phenocopy the symptoms of FXS, and the third in the form of chromosomal structural and numerical abnormalities that can result from problems associated with replication of the repeats including fragile site expression.

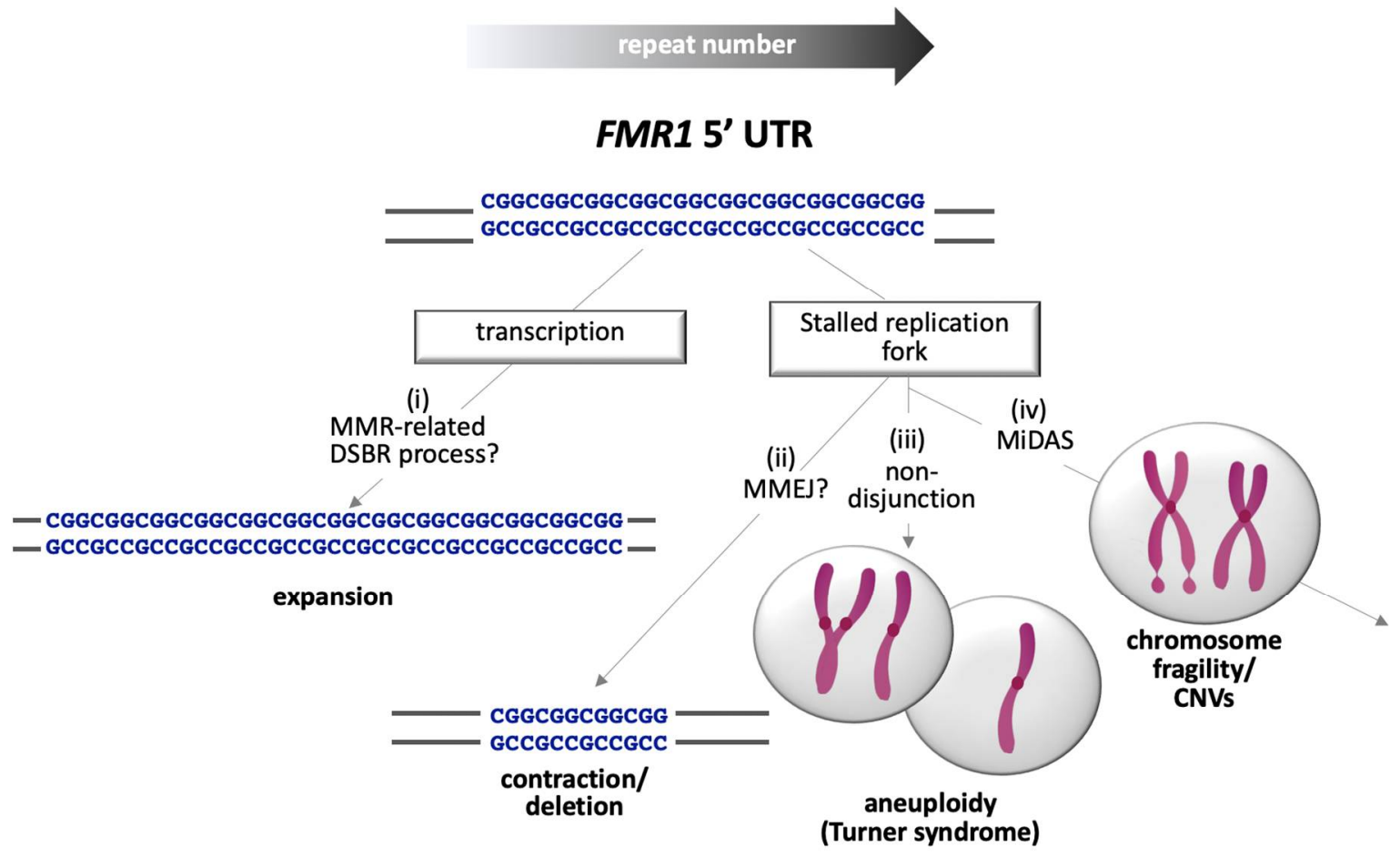

Figure 4. Summary of potential sources of genomic instability associated with PM and FM alleles. Transcription of long CGG-repeat tracts promotes a form of MMR-dependent DSBR that leads to expansion (i). As the repeat number increases, the incidence of replication fork stalling increases. Repair of the stalled fork can lead to contractions or deletions (ii). Aneuploidy can result when stalled forks are not repaired (iii), while chromosome fragility results when repair of the stalled forks by MiDAS is incomplete (iv).

These threats are not limited to the FMR1 locus, but, by extension, are likely to be relevant to the many other CGG-repeat tracts that are seen in human genomes. While the current data indicate that the sources of genetic instability at the FMR1 locus, expansion, contractions/deletions, and chromosome fragility result from different problems caused by the expanded CGG repeat tract, more work is needed to better understand the mechanisms responsible and what, if any, overlap there is in the pathways involved. While, at this point, there is no evidence for a role of MMR in chromosome fragility, the bulk of the evidence points to an important role for MMR proteins in many, if not all, expansions, both in the FXDs and in other repeat expansion diseases. This is relevant as there are some encouraging signs that it may be possible to reduce MMR-dependent expansions 
by targeting components of the MMR machinery like PMS1 that are not associated with significantly increased cancer risk [106].

Funding: The APC was funded by a grant from the IRP of NIDDK (DK057808) to K.U.

Institutional Review Board Statement: Not applicable.

Informed Consent Statement: Not applicable.

Data Availability Statement: Not applicable.

Conflicts of Interest: The authors declare no conflict of interest.

\section{References}

1. Martin, J.P.; Bell, J. A Pedigree of Mental Defect Showing Sex-Linkage. J. Neurol. Psychiatry 1943, 6, 154-157. [CrossRef] [PubMed]

2. Lubs, H.A. A marker X chromosome. Am. J. Hum. Genet. 1969, 21, 231-244.

3. Fu, Y.H.; Kuhl, D.P.; Pizzuti, A.; Pieretti, M.; Sutcliffe, J.S.; Richards, S.; Verkerk, A.J.; Holden, J.J.; Fenwick, R.G., Jr.; Warren, S.T.; et al. Variation of the CGG repeat at the fragile X site results in genetic instability: Resolution of the Sherman paradox. Cell 1991, 67, 1047-1058. [CrossRef]

4. Verkerk, A.J.; Pieretti, M.; Sutcliffe, J.S.; Fu, Y.H.; Kuhl, D.P.; Pizzuti, A.; Reiner, O.; Richards, S.; Victoria, M.F.; Zhang, F.P.; et al. Identification of a gene (FMR-1) containing a CGG repeat coincident with a breakpoint cluster region exhibiting length variation in fragile X syndrome. Cell 1991, 65, 905-914. [CrossRef]

5. Sherman, S.L.; Morton, N.E.; Jacobs, P.A.; Turner, G. The marker (X) syndrome: A cytogenetic and genetic analysis. Ann. Hum. Genet. 1984, 48, 21-37. [CrossRef] [PubMed]

6. Lozano, R.; Rosero, C.A.; Hagerman, R.J. Fragile X spectrum disorders. Intractable Rare Dis. Res. 2014, 3, 134-146. [CrossRef]

7. Malik, I.; Kelley, C.P.; Wang, E.T.; Todd, P.K. Molecular mechanisms underlying nucleotide repeat expansion disorders. Nat. Rev. Mol. Cell Biol. 2021, 22, 589-607. [CrossRef]

8. Grasso, M.; Faravelli, F.; Lo Nigro, C.; Chiurazzi, P.; Sperandeo, M.P.; Argusti, A.; Pomponi, M.G.; Lecora, M.; Sebastio, G.F.; Perroni, L.; et al. Mosaicism for the full mutation and a microdeletion involving the CGG repeat and flanking sequences in the FMR1 gene in eight fragile X patients. Am. J. Med. Genet. 1999, 85, 311-316. [CrossRef]

9. Manor, E.; Jabareen, A.; Magal, N.; Kofman, A.; Hagerman, R.J.; Tassone, F. Prenatal Diagnosis of Fragile X: Can a Full Mutation Allele in the FMR1 Gene Contract to a Normal Size? Front. Genet. 2017, 8, 158. [CrossRef]

10. Prawer, Y.; Hunter, M.; Cronin, S.; Ling, L.; Aliaga Vera, S.; Fahey, M.; Gelfand, N.; Oertel, R.; Bartlett, E.; Francis, D.; et al. Prenatal Diagnosis of Fragile X Syndrome in a Twin Pregnancy Complicated by a Complete Retraction. Genes 2018, 9, 287. [CrossRef]

11. Maia, N.; Loureiro, J.R.; Oliveira, B.; Marques, I.; Santos, R.; Jorge, P.; Martins, S. Contraction of fully expanded FMR1 alleles to the normal range: Predisposing haplotype or rare events? J. Hum. Genet. 2017, 62, 269-275. [CrossRef]

12. Grønskov, K.; Hjalgrim, H.; Bjerager, M.O.; Brondum-Nielsen, K. Deletion of all CGG repeats plus flanking sequences in FMR1 does not abolish gene expression. Am. J. Hum. Genet. 1997, 61, 961-967. [CrossRef]

13. de Graaff, E.; de Vries, B.B.; Willemsen, R.; van Hemel, J.O.; Mohkamsing, S.; Oostra, B.A.; van den Ouweland, A.M. The fragile X phenotype in a mosaic male with a deletion showing expression of the FMR1 protein in $28 \%$ of the cells. Am. J. Med. Genet. 1996, 64, 302-308. [CrossRef]

14. Erbs, E.; Fenger-Gron, J.; Jacobsen, C.M.; Lildballe, D.L.; Rasmussen, M. Spontaneous rescue of a FMR1 repeat expansion and review of deletions in the FMR1 non-coding region. Eur. J. Med. Genet. 2021, 64, 104244. [CrossRef]

15. Tabolacci, E.; Pietrobono, R.; Maneri, G.; Remondini, L.; Nobile, V.; Della Monica, M.; Pomponi, M.G.; Genuardi, M.; Neri, G.; Chiurazzi, P. Reversion to Normal of FMR1 Expanded Alleles: A Rare Event in Two Independent Fragile X Syndrome Families. Genes 2020, 11, 248. [CrossRef]

16. Hirst, M.; Grewal, P.; Flannery, A.; Slatter, R.; Maher, E.; Barton, D.; Fryns, J.P.; Davies, K. Two new cases of FMR1 deletion associated with mental impairment. Am. J. Hum. Genet. 1995, 56, 67-74. [PubMed]

17. MacKenzie, J.J.; Sumargo, I.; Taylor, S.A. A cryptic full mutation in a male with a classical fragile X phenotype. Clin. Genet. 2006, 70, 39-42. [CrossRef]

18. Orrico, A.; Galli, L.; Dotti, M.T.; Plewnia, K.; Censini, S.; Federico, A. Mosaicism for full mutation and normal-sized allele of the FMR1 gene: A new case. Am. J. Med. Genet. 1998, 78, 341-344. [CrossRef]

19. Ferreira, S.I.; Pires, L.M.; Ferrao, J.; Sa, J.; Serra, A.; Carreira, I.M. Mosaicism for FMR1 gene full mutation and intermediate allele in a female foetus: A postzygotic retraction event. Gene 2013, 527, 421-425. [CrossRef]

20. Hayward, B.; Loutaev, I.; Ding, X.; Nolin, S.L.; Thurm, A.; Usdin, K.; Smith, C.B. Fragile X syndrome in a male with methylated premutation alleles and no detectable methylated full mutation alleles. Am. J. Med. Genet. A 2019, 179, 2132-2137. [CrossRef] [PubMed]

21. Latham, G.J.; Coppinger, J.; Hadd, A.G.; Nolin, S.L. The role of AGG interruptions in fragile X repeat expansions: A twenty-year perspective. Front. Genet. 2014, 5, 244. [CrossRef]

22. Cohen, I.L.; Nolin, S.L.; Sudhalter, V.; Ding, X.H.; Dobkin, C.S.; Brown, W.T. Mosaicism for the FMR1 gene influences adaptive skills development in fragile X-affected males. Am. J. Med. Genet. 1996, 64, 365-369. [CrossRef] 
23. Han, X.D.; Powell, B.R.; Phalin, J.L.; Chehab, F.F. Mosaicism for a full mutation, premutation, and deletion of the CGG repeats results in 22\% FMRP and elevated FMR1 mRNA levels in a high-functioning fragile X male. Am. J. Med. Genet. A 2006, 140, 1463-1471. [CrossRef] [PubMed]

24. Pretto, D.; Yrigollen, C.M.; Tang, H.T.; Williamson, J.; Espinal, G.; Iwahashi, C.K.; Durbin-Johnson, B.; Hagerman, R.J.; Hagerman, P.J.; Tassone, F. Clinical and molecular implications of mosaicism in FMR1 full mutations. Front. Genet. 2014, 5, 318. [CrossRef] [PubMed]

25. Verdyck, P.; Berckmoes, V.; De Vos, A.; Verpoest, W.; Liebaers, I.; Bonduelle, M.; De Rycke, M. Chromosome fragility at FRAXA in human cleavage stage embryos at risk for fragile X syndrome. Am. J. Med. Genet. A 2015, 167, 2306-2313. [CrossRef]

26. Dobkin, C.; Radu, G.; Ding, X.H.; Brown, W.T.; Nolin, S.L. Fragile X prenatal analyses show full mutation females at high risk for mosaic Turner syndrome: Fragile X leads to chromosome loss. Am. J. Med. Genet. A 2009, 149, 2152-2157. [CrossRef] [PubMed]

27. Lokanga, R.A.; Kumari, D.; Usdin, K. Common Threads: Aphidicolin-Inducible and Folate-Sensitive Fragile Sites in the Human Genome. Front. Genet. 2021, 12, 1508. [CrossRef] [PubMed]

28. Paulson, H. Repeat expansion diseases. Handb. Clin. Neurol. 2018, 147, 105-123. [CrossRef]

29. Khristich, A.N.; Mirkin, S.M. On the wrong DNA track: Molecular mechanisms of repeat-mediated genome instability. J. Biol. Chem. 2020, 295, 4134-4170. [CrossRef]

30. Brown, R.E.; Freudenreich, C.H. Structure-forming repeats and their impact on genome stability. Curr. Opin. Genet. Dev. 2021, 67, 41-51. [CrossRef] [PubMed]

31. Polleys, E.J.; Freudenreich, C.H. Homologous recombination within repetitive DNA. Curr. Opin. Genet. Dev. 2021, 71, 143-153. [CrossRef] [PubMed]

32. Yudkin, D.; Hayward, B.E.; Aladjem, M.I.; Kumari, D.; Usdin, K. Chromosome fragility and the abnormal replication of the FMR1 locus in fragile X syndrome. Hum. Mol. Genet. 2014, 23, 2940-2952. [CrossRef] [PubMed]

33. Hansen, R.S.; Canfield, T.K.; Lamb, M.M.; Gartler, S.M.; Laird, C.D. Association of fragile X syndrome with delayed replication of the FMR1 gene. Cell 1993, 73, 1403-1409. [CrossRef]

34. Webb, T. Delayed replication of Xq27 in individuals with the fragile X syndrome. Am. J. Med. Genet. 1992, 43, 1057-1062. [CrossRef] [PubMed]

35. James, S.J.; Miller, B.J.; Cross, D.R.; McGarrity, L.J.; Morris, S.M. The essentiality of folate for the maintenance of deoxynucleotide precursor pools, DNA synthesis, and cell cycle progression in PHA-stimulated lymphocytes. Environ. Health Perspect 1993, 101 (Suppl. 5), 173-178. [CrossRef]

36. Usdin, K.; Woodford, K.J. CGG repeats associated with DNA instability and chromosome fragility form structures that block DNA synthesis in vitro. Nucleic Acids Res. 1995, 23, 4202-4209. [CrossRef]

37. Fry, M.; Loeb, L.A. The fragile X syndrome d(CGG)n nucleotide repeats form a stable tetrahelical structure. Proc. Natl. Acad. Sci. USA 1994, 91, 4950-4954. [CrossRef]

38. Mitas, M.; Yu, A.; Dill, J.; Haworth, I.S. The trinucleotide repeat sequence d(CGG)15 forms a heat-stable hairpin containing Gsyn Ganti base pairs. Biochemistry 1995, 34, 12803-12811. [CrossRef]

39. Yu, A.; Barron, M.D.; Romero, R.M.; Christy, M.; Gold, B.; Dai, J.; Gray, D.M.; Haworth, I.S.; Mitas, M. At physiological pH, $\mathrm{d}(\mathrm{CCG}) 15$ forms a hairpin containing protonated cytosines and a distorted helix. Biochemistry 1997, 36, 3687-3699. [CrossRef]

40. Kettani, A.; Kumar, R.A.; Patel, D.J. Solution structure of a DNA quadruplex containing the fragile X syndrome triplet repeat. J. Mol. Biol. 1995, 254, 638-656. [CrossRef]

41. Murat, P.; Guilbaud, G.; Sale, J.E. DNA polymerase stalling at structured DNA constrains the expansion of short tandem repeats. Genome Biol. 2020, 21, 209. [CrossRef]

42. Patel, P.K.; Bhavesh, N.S.; Hosur, R.V. Cation-dependent conformational switches in d-TGGCGGC containing two triplet repeats of Fragile X Syndrome: NMR observations. Biochem. Biophys. Res. Commun. 2000, 278, 833-838. [CrossRef] [PubMed]

43. Fojtik, P.; Vorlickova, M. The fragile X chromosome (GCC) repeat folds into a DNA tetraplex at neutral pH. Nucleic Acids Res. 2001, 29, 4684-4690. [CrossRef]

44. Mariappan, S.V.; Catasti, P.; Chen, X.; Ratliff, R.; Moyzis, R.K.; Bradbury, E.M.; Gupta, G. Solution structures of the individual single strands of the fragile X DNA triplets (GCC)n.(GGC)n. Nucleic Acids Res. 1996, 24, 784-792. [CrossRef] [PubMed]

45. Voineagu, I.; Surka, C.F.; Shishkin, A.A.; Krasilnikova, M.M.; Mirkin, S.M. Replisome stalling and stabilization at CGG repeats, which are responsible for chromosomal fragility. Nat. Struct. Mol. Biol. 2009, 16, 226-228. [CrossRef]

46. Gerhardt, J.; Tomishima, M.J.; Zaninovic, N.; Colak, D.; Yan, Z.; Zhan, Q.; Rosenwaks, Z.; Jaffrey, S.R.; Schildkraut, C.L. The DNA replication program is altered at the FMR1 locus in fragile X embryonic stem cells. Mol. Cell 2014, 53, 19-31. [CrossRef] [PubMed]

47. Bjerregaard, V.A.; Garribba, L.; McMurray, C.T.; Hickson, I.D.; Liu, Y. Folate deficiency drives mitotic missegregation of the human FRAXA locus. Proc. Natl. Acad. Sci. USA 2018, 115, 13003-13008. [CrossRef] [PubMed]

48. Garribba, L.; Bjerregaard, V.A.; Goncalves Dinis, M.M.; Ozer, O.; Wu, W.; Sakellariou, D.; Pena-Diaz, J.; Hickson, I.D.; Liu, Y. Folate stress induces SLX1- and RAD51-dependent mitotic DNA synthesis at the fragile X locus in human cells. Proc. Natl. Acad. Sci. USA 2020, 117, 16527-16536. [CrossRef]

49. Nolin, S.L.; Glicksman, A.; Tortora, N.; Allen, E.; Macpherson, J.; Mila, M.; Vianna-Morgante, A.M.; Sherman, S.L.; Dobkin, C.; Latham, G.J.; et al. Expansions and contractions of the FMR1 CGG repeat in 5,508 transmissions of normal, intermediate, and premutation alleles. Am. J. Med. Genet. A 2019, 179, 1148-1156. [CrossRef] [PubMed] 
50. Nolin, S.L.; Glicksman, A.; Ersalesi, N.; Dobkin, C.; Brown, W.T.; Cao, R.; Blatt, E.; Sah, S.; Latham, G.J.; Hadd, A.G. Fragile X full mutation expansions are inhibited by one or more AGG interruptions in premutation carriers. Genet. Med. 2015, 17, 358-364. [CrossRef] [PubMed]

51. Yrigollen, C.M.; Martorell, L.; Durbin-Johnson, B.; Naudo, M.; Genoves, J.; Murgia, A.; Polli, R.; Zhou, L.; Barbouth, D.; Rupchock, A.; et al. AGG interruptions and maternal age affect FMR1 CGG repeat allele stability during transmission. J. Neurodev. Disord. 2014, 6, 24. [CrossRef] [PubMed]

52. Nolin, S.L.; Houck, G.E., Jr.; Gargano, A.D.; Blumstein, H.; Dobkin, C.S.; Brown, W.T. FMR1 CGG-repeat instability in single sperm and lymphocytes of fragile-X premutation males. Am. J. Hum. Genet. 1999, 65, 680-688. [CrossRef]

53. Glaser, D.; Wohrle, D.; Salat, U.; Vogel, W.; Steinbach, P. Mitotic behavior of expanded CGG repeats studied on cultured cells: Further evidence for methylation-mediated triplet repeat stability in fragile X syndrome. Am. J. Med. Genet. 1999, 84, 226-228. [CrossRef]

54. Wohrle, D.; Salat, U.; Hameister, H.; Vogel, W.; Steinbach, P. Demethylation, reactivation, and destabilization of human fragile X full-mutation alleles in mouse embryocarcinoma cells. Am. J. Hum. Genet. 2001, 69, 504-515. [CrossRef] [PubMed]

55. Zhao, X.; Gazy, I.; Hayward, B.; Pintado, E.; Hwang, Y.H.; Tassone, F.; Usdin, K. Repeat Instability in the Fragile X-Related Disorders: Lessons from a Mouse Model. Brain Sci. 2019, 9, 52. [CrossRef]

56. Gazy, I.; Hayward, B.; Potapova, S.; Zhao, X.; Usdin, K. Double-strand break repair plays a role in repeat instability in a fragile X mouse model. DNA Repair 2019, 74, 63-69. [CrossRef]

57. Møllersen, L.; Rowe, A.D.; Larsen, E.; Rognes, T.; Klungland, A. Continuous and periodic expansion of CAG repeats in Huntington's disease R6/1 mice. PLoS Genet. 2010, 6, e1001242. [CrossRef]

58. Zhou, Y.; Kumari, D.; Sciascia, N.; Usdin, K. CGG-repeat dynamics and FMR1 gene silencing in fragile X syndrome stem cells and stem cell-derived neurons. Mol. Autism. 2016, 7, 42. [CrossRef]

59. Kennedy, L.; Shelbourne, P.F. Dramatic mutation instability in HD mouse striatum: Does polyglutamine load contribute to cell-specific vulnerability in Huntington's disease? Hum. Mol. Genet. 2000, 9, 2539-2544. [CrossRef]

60. Genetic Modifiers of Huntington's Disease (GeM-HD) Consortium. CAG Repeat Not Polyglutamine Length Determines Timing of Huntington's Disease Onset. Cell 2019, 178, 887-900. [CrossRef]

61. Massey, T.H.; Jones, L. The central role of DNA damage and repair in CAG repeat diseases. Dis. Model. Mech. 2018, 11, dmm031930. [CrossRef]

62. Kratz, K.; Artola-Boran, M.; Kobayashi-Era, S.; Koh, G.; Oliveira, G.; Kobayashi, S.; Oliveira, A.; Zou, X.; Richter, J.; Tsuda, M.; et al. FANCD2-Associated Nuclease 1 Partially Compensates for the Lack of Exonuclease 1 in Mismatch Repair. Mol. Cell Biol. 2021, 41, e0030321. [CrossRef]

63. Zhao, X.N.; Usdin, K. FAN1 protects against repeat expansions in a Fragile X mouse model. DNA Repair 2018, 69, 1-5. [CrossRef]

64. Zhao, X.; Zhang, Y.; Wilkins, K.; Edelmann, W.; Usdin, K. MutLgamma promotes repeat expansion in a Fragile X mouse model while EXO1 is protective. PLoS Genet. 2018, 14, e1007719. [CrossRef]

65. Zhao, X.N.; Lokanga, R.; Allette, K.; Gazy, I.; Wu, D.; Usdin, K. A MutSbeta-Dependent Contribution of MutSalpha to Repeat Expansions in Fragile X Premutation Mice? PLoS Genet. 2016, 12, e1006190. [CrossRef]

66. Zhao, X.N.; Kumari, D.; Gupta, S.; Wu, D.; Evanitsky, M.; Yang, W.; Usdin, K. Mutsbeta generates both expansions and contractions in a mouse model of the Fragile X-associated disorders. Hum. Mol. Genet. 2015, 24, 7087-7096. [CrossRef] [PubMed]

67. Lokanga, A.R.; Zhao, X.N.; Entezam, A.; Usdin, K. X inactivation plays a major role in the gender bias in somatic expansion in a mouse model of the fragile X-related disorders: Implications for the mechanism of repeat expansion. Hum. Mol. Genet. 2014, 23, 4985-4994. [CrossRef] [PubMed]

68. Zhao, X.N.; Usdin, K. Timing of Expansion of Fragile X Premutation Alleles During Intergenerational Transmission in a Mouse Model of the Fragile X-Related Disorders. Front. Genet. 2018, 9, 314. [CrossRef]

69. Lokanga, R.A.; Zhao, X.N.; Usdin, K. The mismatch repair protein MSH2 is rate limiting for repeat expansion in a fragile X premutation mouse model. Hum. Mutat. 2014, 35, 129-136. [CrossRef] [PubMed]

70. Hayward, B.E.; Steinbach, P.J.; Usdin, K. A point mutation in the nuclease domain of MLH3 eliminates repeat expansions in a mouse stem cell model of the Fragile X-related disorders. Nucleic Acids Res. 2020, 48, 7856-7863. [CrossRef]

71. Lipkin, S.M.; Moens, P.B.; Wang, V.; Lenzi, M.; Shanmugarajah, D.; Gilgeous, A.; Thomas, J.; Cheng, J.; Touchman, J.W.; Green, E.D.; et al. Meiotic arrest and aneuploidy in MLH3-deficient mice. Nat. Genet. 2002, 31, 385-390. [CrossRef]

72. Cannavo, E.; Sanchez, A.; Anand, R.; Ranjha, L.; Hugener, J.; Adam, C.; Acharya, A.; Weyland, N.; Aran-Guiu, X.; Charbonnier, J.B.; et al. Regulation of the MLH1-MLH3 endonuclease in meiosis. Nature 2020, 586, 618-622. [CrossRef]

73. Miller, C.J.; Kim, G.Y.; Zhao, X.; Usdin, K. All three mammalian MutL complexes are required for repeat expansion in a mouse cell model of the Fragile X-related disorders. PLoS Genet. 2020, 16, e1008902. [CrossRef]

74. Sweder, K.S.; Hanawalt, P.C. Transcription-coupled DNA repair. Science 1993, 262, 439-440. [CrossRef]

75. Zhao, X.N.; Usdin, K. Gender and cell-type-specific effects of the transcription-coupled repair protein, ERCC6/CSB, on repeat expansion in a mouse model of the fragile X-related disorders. Hum. Mutat. 2014, 35, 341-349. [CrossRef]

76. Zhao, X.N.; Usdin, K. The transcription-coupled repair protein ERCC6/CSB also protects against repeat expansion in a mouse model of the fragile X premutation. Hum. Mutat. 2015, 36, 482-487. [CrossRef] [PubMed]

77. Groh, M.; Lufino, M.M.; Wade-Martins, R.; Gromak, N. R-loops associated with triplet repeat expansions promote gene silencing in Friedreich ataxia and fragile X syndrome. PLoS Genet. 2014, 10, e1004318. [CrossRef] [PubMed] 
78. Loomis, E.W.; Sanz, L.A.; Chedin, F.; Hagerman, P.J. Transcription-associated R-loop formation across the human FMR1 CGGrepeat region. PLoS Genet. 2014, 10, e1004294. [CrossRef] [PubMed]

79. Kumari, D.; Usdin, K. Sustained expression of FMR1 mRNA from reactivated fragile X syndrome alleles after treatment with small molecules that prevent trimethylation of H3K27. Hum. Mol. Genet. 2016, 25, 3689-3698. [CrossRef]

80. Abu Diab, M.; Mor-Shaked, H.; Cohen, E.; Cohen-Hadad, Y.; Ram, O.; Epsztejn-Litman, S.; Eiges, R. The G-rich Repeats in FMR1 and C9orf72 Loci Are Hotspots for Local Unpairing of DNA. Genetics 2018, 210, 1239-1252. [CrossRef]

81. Sollier, J.; Stork, C.T.; Garcia-Rubio, M.L.; Paulsen, R.D.; Aguilera, A.; Cimprich, K.A. Transcription-coupled nucleotide excision repair factors promote R-loop-induced genome instability. Mol. Cell 2014, 56, 777-785. [CrossRef]

82. Teng, Y.; Yadav, T.; Duan, M.; Tan, J.; Xiang, Y.; Gao, B.; Xu, J.; Liang, Z.; Liu, Y.; Nakajima, S.; et al. ROS-induced R loops trigger a transcription-coupled but BRCA1/2-independent homologous recombination pathway through CSB. Nat. Commun. 2018, 9, 4115. [CrossRef]

83. Kovtun, I.V.; Liu, Y.; Bjoras, M.; Klungland, A.; Wilson, S.H.; McMurray, C.T. OGG1 initiates age-dependent CAG trinucleotide expansion in somatic cells. Nature 2007, 447, 447-452. [CrossRef] [PubMed]

84. Møllersen, L.; Rowe, A.D.; Illuzzi, J.L.; Hildrestrand, G.A.; Gerhold, K.J.; Tveteras, L.; Bjolgerud, A.; Wilson, D.M., 3rd; Bjoras, M.; Klungland, A. Neil1 is a genetic modifier of somatic and germline CAG trinucleotide repeat instability in R6/1 mice. Hum. Mol. Genet. 2012, 21, 4939-4947. [CrossRef]

85. Kadyrova, L.Y.; Gujar, V.; Burdett, V.; Modrich, P.L.; Kadyrov, F.A. Human MutLgamma, the MLH1-MLH3 heterodimer, is an endonuclease that promotes DNA expansion. Proc. Natl. Acad. Sci. USA 2020, 117, 3535-3542. [CrossRef] [PubMed]

86. Kononenko, A.V.; Ebersole, T.; Vasquez, K.M.; Mirkin, S.M. Mechanisms of genetic instability caused by (CGG)n repeats in an experimental mammalian system. Nat. Struct. Mol. Biol. 2018, 25, 669-676. [CrossRef] [PubMed]

87. Cohen, S.; Guenolé, A.; Marnef, A.; Clouaire, T.; Puget, N.; Rocher, V.; Arnould, C.; Aguirrebengoa, M.; Genais, M.; Vernekar, D; ; et al. BLM-dependent Break-Induced Replication handles Double-strand breaks in transcribed chromatin upon impaired RNA:DNA hybrids dissolution. bioRxiv 2005. [CrossRef]

88. Marnef, A.; Legube, G. R-loops as Janus-faced modulators of DNA repair. Nat. Cell Biol. 2021, 23, 305-313. [CrossRef]

89. Nakamori, M.; Panigrahi, G.B.; Lanni, S.; Gall-Duncan, T.; Hayakawa, H.; Tanaka, H.; Luo, J.; Otabe, T.; Li, J.; Sakata, A.; et al. A slipped-CAG DNA-binding small molecule induces trinucleotide-repeat contractions in vivo. Nat. Genet. 2020, 52, 146-159. [CrossRef]

90. Su, X.A.; Freudenreich, C.H. Cytosine deamination and base excision repair cause R-loop-induced CAG repeat fragility and instability in Saccharomyces cerevisiae. Proc. Natl. Acad. Sci. USA 2017, 114, E8392-E8401. [CrossRef]

91. Kim, J.C.; Harris, S.T.; Dinter, T.; Shah, K.A.; Mirkin, S.M. The role of break-induced replication in large-scale expansions of (CAG)n/(CTG)n repeats. Nat. Struct. Mol. Biol. 2017, 24, 55-60. [CrossRef]

92. Goldmann, J.M.; Veltman, J.A.; Gilissen, C. De Novo Mutations Reflect Development and Aging of the Human Germline. Trends Genet. 2019, 35, 828-839. [CrossRef]

93. Reyniers, E.; Vits, L.; De Boulle, K.; Van Roy, B.; Van Velzen, D.; de Graaff, E.; Verkerk, A.J.; Jorens, H.Z.; Darby, J.K.; Oostra, B.; et al. The full mutation in the FMR-1 gene of male fragile X patients is absent in their sperm. Nat. Genet. 1993, 4, 143-146. [CrossRef] [PubMed]

94. Quan, F.; Grompe, M.; Jakobs, P.; Popovich, B.W. Spontaneous deletion in the FMR1 gene in a patient with fragile X syndrome and cherubism. Hum. Mol. Genet. 1995, 4, 1681-1684. [CrossRef] [PubMed]

95. de Graaff, E.; Rouillard, P.; Willems, P.J.; Smits, A.P.; Rousseau, F.; Oostra, B.A. Hotspot for deletions in the CGG repeat region of FMR1 in fragile X patients. Hum. Mol. Genet. 1995, 4, 45-49. [CrossRef] [PubMed]

96. Schmucker, B.; Ballhausen, W.G.; Pfeiffer, R.A. Mosaicism of a microdeletion of 486 bp involving the CGG repeat of the FMR1 gene due to misalignment of GTT tandem repeats at chi-like elements flanking both breakpoints and a full mutation. Hum. Genet. 1996, 98, 409-414. [CrossRef] [PubMed]

97. Mila, M.; Castellvi-Bel, S.; Sanchez, A.; Lazaro, C.; Villa, M.; Estivill, X. Mosaicism for the fragile X syndrome full mutation and deletions within the CGG repeat of the FMR1 gene. J. Med. Genet. 1996, 33, 338-340. [CrossRef] [PubMed]

98. Mannermaa, A.; Pulkkinen, L.; Kajanoja, E.; Ryynanen, M.; Saarikoski, S. Deletion in the FMR1 gene in a fragile-X male. Am. J. Med. Genet. 1996, 64, 293-295. [CrossRef]

99. Fan, H.; Booker, J.K.; McCandless, S.E.; Shashi, V.; Fleming, A.; Farber, R.A. Mosaicism for an FMR1 gene deletion in a fragile X female. Am. J. Med. Genet. A 2005, 136, 214-217. [CrossRef]

100. Goncalves, T.F.; dos Santos, J.M.; Goncalves, A.P.; Tassone, F.; Mendoza-Morales, G.; Ribeiro, M.G.; Kahn, E.; Boy, R.; Pimentel, M.M.; Santos-Reboucas, C.B. Finding FMR1 mosaicism in Fragile X syndrome. Expert Rev. Mol. Diagn. 2016, 16, 501-507. [CrossRef]

101. Luo, S.; Huang, W.; Chen, C.; Pan, Q.; Duan, R.; Wu, L. An novel deletion to normal size in the sperm of a fragile X full mutation male. Clin. Genet. 2014, 86, 295-297. [CrossRef] [PubMed]

102. Wyatt, D.W.; Feng, W.; Conlin, M.P.; Yousefzadeh, M.J.; Roberts, S.A.; Mieczkowski, P.; Wood, R.D.; Gupta, G.P.; Ramsden, D.A. Essential Roles for Polymerase theta-Mediated End Joining in the Repair of Chromosome Breaks. Mol. Cell 2016, 63, 662-673. [CrossRef] 
103. Cecconi, M.; Forzano, F.; Rinaldi, R.; Cappellacci, S.; Grammatico, P.; Faravelli, F.; Dagna Bricarelli, F.; Di Maria, E.; Grasso, M. A single nucleotide variant in the FMR1 CGG repeat results in a "Pseudodeletion" and is not associated with the fragile $\mathrm{X}$ syndrome phenotype. J. Mol. Diagn. 2008, 10, 272-275. [CrossRef]

104. Tabolacci, E.; Pomponi, M.G.; Pietrobono, R.; Chiurazzi, P.; Neri, G. A unique case of reversion to normal size of a maternal premutation FMR1 allele in a normal boy. Eur. J. Hum. Genet. 2008, 16, 209-214. [CrossRef]

105. Tarleton, J.; Kenneson, A.; Taylor, A.K.; Crandall, K.; Fletcher, R.; Casey, R.; Hart, P.S.; Hatton, D.; Fisch, G.; Warren, S.T. A single base alteration in the CGG repeat region of FMR1: Possible effects on gene expression and phenotype. J. Med. Genet. 2002, 39, 196-200. [CrossRef] [PubMed]

106. Suelves, N.; Kirkham-McCarthy, L.; Lahue, R.S.; Gines, S. A selective inhibitor of histone deacetylase 3 prevents cognitive deficits and suppresses striatal CAG repeat expansions in Huntington's disease mice. Sci. Rep. 2017, 7, 6082. [CrossRef] [PubMed] 